\title{
Dari Kesaksian Iman ke Simbiosis Agama: Meninjau Konsep Dialog Calvin E. Shenk Bagi Perjumpaan Islam-Kristen di Maluku
}

\author{
Yohanes Parihala ${ }^{1, *}$, Kritsno Saptenno ${ }^{2}$ \\ 1 Universitas Kristen Indonesia Maluku, Indonesia; e-mail: parihalayoh@gmail.com \\ 2 Universitas Kristen Indonesia Maluku, Indonesia, e-mail: kritsnosaptenno@yahoo.com \\ * Correspondence
}

Received: 2020-04-27; Accepted: 2020-05-27; Published: 2020-05-30

\begin{abstract}
This study aims to analyse the thoughts of Calvin E. Shenk, a Christian missiologist, who criticized the concept of tripolar typology in the reality of religious pluralism, which was seen as reducing Christian faith. Calvin E. Shenk offers the idea of authentic dialogue, dialogue is as a form of witness of faith. However, Shenk's thoughts cannot simply be applied in the reality of encounters between Muslims and Christians in Maluku, which only emerged from the religious conflict of in 1999-2004. Both the analysis of Shenk's thoughts and the analysis of the context of religious presentation in Maluku, uses the approach of literature study in qualitative research methods. Finally, this study offers a dialogue paradigm in the context of interfaith relations in Maluku that embraces the uniqueness of each religion, including the praxis of the witness of faith, but does not neglect an important dimension that all religions need each other, and that is the symbiosis of religion.
\end{abstract}

Keywords: Witness; Dialogeu; and Symbiotic

Abstrak: Kajian ini bertujuan untuk meninjau pemikiran Calvin E. Shenk, seorang misiolog Kristen, yang mengkritik konsep tipologi tripolar dalam realitas kemajemukan agama, yang dipandang mereduksi iman Kristen. Calvin E. Shenk menawarkan gagasan tentang dialog yang otentik yaitu dialog sebagai bentuk kesaksian iman. Namun, pemikiran Shenk tidak begitu saja dapat diterapkan di dalam realitas perjumpaan antar umat beragama Islam dan Kristen di Maluku, yang baru keluar dari kemelut konflik bernuansa agama pada tahun 1999-2004. Tinjauan terhadap pemikiran Shenk dan analisis konteks perjuampaan agama di Maluku menggunakan pendekatan studi kepustakaan di dalam metode penelitian kualitatif. Pada akhirnya, kajian ini menawarkan suatu paradigma dialog di dalam konteks hubungan antar agama di Maluku yang merangkul keunikan setiap agama, termasuk praksis kesaksian iman, namun tidak mengabaikan suatu dimensi penting bahwa semua agama saling membutuhkan, dan itu adalah simbiosis agama.

Kata Kunci: Kesaksian; Dialog; dan Simbiosis

\section{Pendahuluan}

Gagasan mengenai dialog antar agama untuk menjembatani perbedaan, sekaligus mengatasi perseteruan telah lama digemakan. Dalam kajian Dwi Wahyuni, dijelaskan bahwa dialog keagamaan di Indonesia telah dimulai sejak awal tahun 1960. Wahyuni menjelaskannya secara historis dialog keagamaan di Indonesia berawal pada tahun1960-an. Partai Komunis Indonesia mendapat posisi startegis dipemerintahan dengan dukungan presiden Sukarno ketika itu. Namun setelah peristiwa 1965, Partai Komunis Indonesia serta paham komunisme-nya dilarang pemerintahan Suharto dan pada saat yang sama juga, masyarakat Indonesia harus memilih salah satu agama resmi yang diakui 
pemerintah. Dengan kondisi saat itu maka gereja-gereja dibanjiri oleh orang-orang yang baru menjadi umat Kristen. Hal itu paling tidak menimbulkan dua masalah bagi hubungan antaragama di Indonesia, terutama hubungan antar Islam dan Kristen. Pertama, berkembangnya anggapan bahwa gereja telah memberikan tempat perlidungan bagi anggota PKI. Kedua, meningkatkan jumlah umat Kristen dan gereja di Indonesia, terutama di pulau Jawa"(Wahyuni, 2019).

Franz Maginis-Suseno sejak tahun 1999 telah menulis artikelnya dengan mempertanyakan mengenai apakah dialog antar-agama sedang di jalan buntu? Dalam tulisannya itu, Suseno menyebutkan selama lebih dari 30 tahun sudah berlangsung dialog antar agama, seperti Kristen dan Islam di Indonesia, dalam pelbagai forum dan format. Ada dialog agak resmi yang disponsori oleh kementrian agama atau pemerintah. Ada banyak dialog dalam bentuk seminar tentang hubungan antar-agama. Banyak pula dialog informal, dan dialog lokal yang melibatkan antar umat beragama di wilayah setempat. Akan tetapi seiring dengan itu, berbagai persoalan seperti pengrusakan rumahrumah Ibadah terus terjadi. Konflik antar umat beragama yang berbeda tidak terelakkan. Kubu-kubu agama makin tertutup. Pola relasi mayoritas versus minoritas menajam. Kendati demikian, dalam simpulannya, Suseno menegaskan bahwa dialog masih harus terus dijalankan, kendati ada kekecewaan, tetapi agama-agama perlu terus berupaya merajut kerjasama untuk kebaikan hidup bersama (Magnis Suseno, 2003).

Dalam kasus konflik berwajah agama di Maluku tahun 1999-2004, berbagai pendekatan penyelesaian konflik dilakukan, mulai dari diplomasi politik pemerintah dan peran militer, hingga berbagai pendekatan dialog dengan keterlibatan berbagai pihak, seperti pemerintah, tokoh masyarakat, termasuk tokoh agama hingga dialog antar umat beragama.

Dalam konteks dialog itulah, Nujib dan Rumahuru, yang menjadikan konflik Maluku sebagai salah satu lokus studinya, menyebutkan dalam dialog diperlukan suatu paradigma transformatif, sehingga dialog dapat mentrasnformasi kehidupan masyarakat yang berkonflik. Pendekatan transformatif yang dimaksudkan adalah lebih menitik-beratkan perjumpaan dan dialog agamaagama terkait dengan persoalan humanis secara bersama"(Mujib \& Z. Rumahuru, 2010).

Artikel ini menghadapkan konsep Calvin E Shenk mengenai pendekatan dialog antar agama yang berbasis pada kesaksian iman. Dalam bukunya yang fenomenal, Who do you say that I am? Christians Encounter Other Religious, Shenk berpendapat dialog yang otentik tampak dari upaya mengkomunikasikan kekhasan tradisi iman, atau yang dibahasakannya dengan semangat kesaksian iman. Berbeda dengan dialog-dialog yang cenderung menekankan konvergensi dan menghindari gesekan, dialog sebagai kesaksian iman justru dapat menghadirkan ketenangan di antara pihak yang berdialog. Bagi Shenk, dialog yang otentik seringkali justru memicu ketidaknyamanan sebagai imbas dari proses komunikasi kebenaran. Standar otentisitas dialog seperti yang diungkapkan Shenk, pada satu sisi menjadi kritik bagi praksis dialog yang cenderung formal ketika menyentuh ranah teologis. Hasilnya, dialog tidak berhasil mengurai kecurigaan karena justru menghindari sentuhan pada ranah sensitif dari agama, seperti kebenaran maupun keselamatan (Shenk, 2010).

Tetapi pada sisi lain, standar itu juga melahirkan suatu tantangan baru dalam konteks umat beragama yang sedang berjuang untuk memulihkan relasi pasca konflik, seperti di Maluku. Masyarakat Maluku yang baru keluar dari konflik berwajah agama, saat ini sedang terus berupaya membangun kembali sikap saling percaya (trustable) untuk menjaga dan melestarikan kedamaian yang tercipta. Dalam konteks itu, konsep dialog yang disarankan Shenk dapat menjadi peluang memperkuat fondasi keagamaan atau keimanan seseorang sebagai basis membangun perdamaian, atau sebaliknya melahirkan tantangan tersendiri karena telah menyentuh ranak keunikan setiap agama. Dalam konteks perjumpaan Islam-Kristen di Maluku pasca konflik, artikel ini mencoba menjawab pertanyaan mendasarnya yakni: apakah penerapan dialog otentik yang digagas Calvin E. Shenk memungkinkan untuk diterapkan di daerah pasca konflik seperti Maluku?

Studi tentang konsep kesaksian iman Kristen terhadap agama lain yang terinspirasi dari pemikiran Shenk telah dilakukan sebelumnya oleh Jason J. Yoder dalam artikelnya, The Trinity and Christian Witness to Muslims. Yoder menggunakan paradigma kesaksian iman yang ditawarkan Shenk dalam membangun dialog dengan umat Muslim yang bertujuan untuk menjelaskan kembali 
kesalahpahaman tentang trinitas oleh umat Muslim (misunderstanding of the Trinity by Muslims). Menurut Yoder, melalui kesaksian iman, the Christian should invite the Muslim to experience personally the one God who sustains, saves, and abides (Yoder, 1994). Berbeda dengan kajian Yoder, artikel ini melakukan evaluasi kritis terhadap konsep kesaksian iman sebagai dialog ontetik - yang dipandang tidak begitu relevan jika diterapkan dalam konteks perjumpaan Islam-Kristen di Maluku. Itu sebabnya, penulis menawarkan suatu paradigma lain, yakni simbiosis agama.

Konsep simbiosis agama diperkenalkan oleh Aloysius Pieris yang bertolak dari paham kristologis menuju kepada konsep dialog antar umat beragama dengan berfokus pada perjuangan bersama mengentaskan masalah kemiskinan yang disebutnya sebagai locus atau konteks berteologi agama-agama di Asia (Pieris, 2004). Dalam artikel ini, penulis menggunakan paradigma simbiosis agama yang dijelaskan oleh Pieris dengan locus yang berbeda, bukan lagi soal kemiskinan melainkan mengenai konteks perjumpaan Islam-Kristen untuk membangun dan merawat perdamaian di Maluku pasca konflik. Gagasan simbiosis agama juga dimunculkan dalam kajian Kamarusdiana mengenai Al-Qur'an dan Relasi Antar Umat Beragama. Menurutnya, Islam sebagai agama yang ramah telah menunjukkan nilai-nilai ajaran yang inklusif. Nilai-nilai universal Islam yang luhur dengan konsep Rahmatan Lil 'Alamin memberikan distingsi tersendiri. Demi terciptanya kerukunan antar umat beragama, sudah semestinya terbangun relasi saling memberikan timbal balik antara agama (simbiosis agama) yang satu dengan yang lain dalam konteks bermasyarakat (Kamarusdiana, 2018). Analisis Kamarudiana belum secara lengkap membahas mengenai konsep simbiosis agama, tetapi telah memberikan suatu informasi awal bahwa konsep tersebut juga dapat dibangun dari perspetif agama Islam. Artikel ini membahasnya berangkat dari perspektif Kristen untuk merefleksikan pengalaman perjumpaan dan dialog antar Islam dan Kristen di Maluku.

Dialog antaragama di Indonesia telah banyak dibahas dalam berbagai kajian. Pembahasan konsep dialog juga bertumpuh pada berbagai perspektif, antara lain: menolak eksklusivisme dan insklusivisme, serta mengapresiasi pluralisme (Bahri, 2014); dialog antaragama dengan spiritualitas passing over (Rahmat, 2017); dialog dalam perspektif Nurcholish Madjid yang berorientasi pada tanggung jawab kemanusiaan (Moko, 2017; Susanto, 2007; Zaprulkhan, 2018), dan seterusnya. Berbeda dengan berbagai kajian yang disebutkan, artikel ini bertujuan untuk melakukan analisis kritis terhadap konsep dialog otentik menurut Calvin E Shenk yang disebutnya sebagai kesaksian iman, sekaligus menawarkan konsep perjumpaan dan dialog Islam-Kristen di Maluku berdasarkan perspektif simbiosis agama untuk merawat perdamaian di Maluku pasca konflik kemanusiaan tahun 1999-2004.

Studi ini menggunakan metode penelitian kualitatif, yang dijelaskan oleh Sugiono sebagai suatu metode yang digunakan untuk mendapatkan data yang mendalam, suatu data yang mengandung makna. Data kualitatif itu berbentuk kata, kalimat, gerak tubuh, foto, dan seterusnya, yang perlu diberikan makna atau diinterpretasi (Sugiyono, 2016). Dengan analisis deskriptis kualitatif berdasarkan studi kepustakaan, maka data terkait pemikiran Shenk didalogkan secara kritis dengan data deskriptis dari para pemikir lain mengenai konsep dialog di dalam perjumpaan Islam dan Kristen, dan juga berbagai deskripsi analitis mengenai realitas konflik dan perdamaian di Maluku.

\section{Konsep Dialog Otentik Menurut Calvin E. Shenk}

\section{Melampaui tipologi tripolar dan menggemakan keunikan Yesus}

Pendekatan Shenk dimulai dari kritiknya terhadap tipologi tripolar, ekslusivisme-inklusivisme dan pluralisme. Ketiga posisi itu dikritik Shenk, namun karena ekslusivisme dan inklusivisme masih memberi ruang yang besar bagi keunikan Yesus (Shenk, 1997), kritik Shenk lebih banyak diarahkan kepada pluralisme (Shenk, 1997). Pluralisme menurut Shenk berusaha meyakinkan umat beragama bahwa kekhasan tradisi iman dalam agama-agama hanya bersifat superfisial. Setiap agama terhubung dengan cara yang terbatas untuk melukiskan yang Ilahi, seperti simbol dan sistem bahasa. Hal ini dipertegas oleh pengusung pluralisme dalam kekristenan seperti John Hick. Para pendukung 
pluralisme seperti Hick menegaskan bahwa kekhasan tradisi dalam agama-agama tidak boleh mengaburkan visi semua agama untuk saling belajar dan bertumbuh. Menurut Hick:

The hypothesis may thus provide a framework for inter-faith dialogue, and an explicit basis for the hope that each tradition may learn from and be changed by its encounter with the others. For if each represents a different human perspective on the Real, each may be able to enlarge its own vision by trying to look through the lenses that others have developed (Hick, 1993).

Shenk kemudian mensiyalir bahwa pluralisme memiliki tendensi untuk memaknai kebenaran hanya bersifat komplementer. Pluralisme mengabaikan fakta bahwa kebenaran antar agama bisa saja bersifat kontradiktif. Pemahaman yang cenderung simplisitis ini menurut Shenk akan berimbas kepada komitmen terhadap iman Kristen. Menurut Shenk, pluralisme menerapkan toleransi yang keliru dan justru menunjukan ketidakpedulian kepada kebenaran (Shenk, 1997). Penekanan terhadap pluralisme dapat menghilangkan suara profetis Kristen di tengah kemajemukan.

Dari kritik tersebut, Shenk berusaha menggemakan kembali posisi sentral Yesus yang tenggelam oleh pluralisme. Menurut Shenk, Yesus Kristus adalah wahyu khusus (special revalation) dan berbeda dengan wahyu umum (general revalation) yang ada dalam setiap agama. Wahyu umum dalam pemikiran Shenk, adalah kesadaran manusia akan Tuhan karena manusia adalah citra Tuhan yang mendiami dunia. Namun menurut Shenk, kebenaran dari wahyu umum itu masih bersifat samar-samar, baru dalam kehadiran Yesus, semua kebenaran dalam wahyu umum mengalami kepenuhan (Shenk, 1997).

Konsekuensi dari posisi Yesus sebagai wahyu khusus membuat umat Kristen harus menerima Yesus sebagai kebenaran normatif. Kebenaran dalam Yesus bukan hasil konsensus dalam pemahaman kebenaran sebagai respons kultural, melainkan sesuatu pemberian (given) dari Allah. Menurut Shenk, kebenaran normatif itulah yang menurut Shenk harus dikomunikasikan dalam hubungan dengan agama-agama lain, bukan perubahan nilai seperti relativisme ataupun pluralisme (Shenk, 1997).

Kehadiran Yesus sebagai wahyu khusus termaktub dalam keunikannya seperti inkarnasi, penebusan, keselamatan dan kebangkitan. Keunikan ini menurut Shenk tidak sekadar membedakan iman Kristen dari agama lain tapi juga dapat menjadi dasar bagi kesaksian Kristen. Namun, keunikan Yesus itu sering tereduksi oleh konsep-konsep yang kurang menekankan keunikannya. Shenk memberi contoh gambaran Yesus dalam agama Islam dan Yahudi yang dipandang sebagai nabi dan guru.

Meresponi kecenderungan itu, Shenk menegaskan bahwa gambaran Yesus dalam agama lain atau yang disebutnya sebagai Christ principle, tidak boleh mengabaikan Jesus event atau kehadiran Yesus yang nyata dalam sejarah dan injil. Menurut Shenk, iman Kristen akan kehilangan maknanya ketika hubungan antara Jesus event dan Christ principle dilonggarkan. Iman Kristen tidak dapat dilepaskan daripada upaya memahami Tuhan dalam Yesus yang hidup dalam sejarah. Bagi Shenk, semua konsep kristologi harus berakar dari kesaksian alkitab dan tidak boleh mengabaikan segi historitas dari pribadi Yesus (Shenk, 1997).

\section{Berdialog sebagai bentuk kesaksian (form of witness)}

Penekanan Shenk kepada keunikan Yesus kemudian menjadi dasar bagi ide kesaksian dalam pendekatannya. Menurut Shenk, dasar bagi kesaksian sangatlah biblis, karena kisah-kisah dalam Perjanjian Baru secara tegas meminta agar orang Kristen mengenalkan kebenaran dan keunikan Yesus. Shenk bahkan menarik kesimpulan bahwa teologi Perjanjian Baru (1 Yoh 1:3) adalah teologi kesaksian (theology of witness) (Shenk, 1997). Oleh karena itu, menjadi saksi Kristus adalah sebuah keniscayaan bagi orang yang mengaku sebagai pengikut Kristus. Kebenaran Kristus yang telah diterima harus dibagikan kepada setiap manusia termasuk umat beragama lain. Penekanan terhadap tugas kesaksian menurut Shenk semakin diperlukan dalam konteks pluralitas dan globalisasi. Dalam konteks perjumpaan dengan umat beragama lain, Shenk melihat bahwa dialog dapat menjadi salah satu bentuk kesaksian iman. 
Menurut Shenk, dialog dalam bingkai kesaksian memiliki pendasaran secara biblis dalam inkarnasi Yesus. Inkarnasi dapat menjadi dasar bagi dialog karena lewat inkarnasi Allah dalam Yesus "berdialog" dengan manusia. Inkarnasi tidak sekadar menjadi dialog, tetapi juga menjadi pola (pattern) bagi terjadinya dialog yang berkelanjutan di antara manusia (Shenk, 1997). Shenk menilai bahwa dalam pelayanannya, Yesus memilih berdialog secara serius dengan orang lain ketimbang menampilkan kelihaiannya menjawab pertanyaan (Mat 21:40; Luk 10:36).

Dari dasar dan pola dialog itu, Shenk mengemukakan beberapa jenis dialog seperti dialog kehidupan, dialog karya maupun dialog isu teologis. Dialog kehidupan atau living dialogue, adalah dialog yang terjadi ketika orang Kristen berbagi ruang kehidupan dengan umat beragama lain. Bagi Shenk, dialog kehidupan menunjukan bahwa sebuah dialog terkadang lebih membutuhkan hidup bersama lebih dari sekedar berbicara bersama (Shenk, 1997). Hubungan yang akrab dapat membuat umat beragama lain mengubah sudut pandang ketimbang memenangkan argumen yang dapat memicu semangat persaingan. Kendati demikian, dialog kehidupan tetap harus berada dalam koridor kesaksian iman. Alih-alih hanya sekedar memenuhi norma dan nilai dalam masyarakat, Shenk menilai bahwa dialog kehidupan dapat menjadi kesempatan bersaksi bagi orang Kristen. Dialog kehidupan memungkinkan terciptanya relasi yang sejuk, dapat menjadi jalan agar konten dialog yaitu kebenaran Kristus dapat didengarkan. Bagi Shenk, relasi yang baik sangat menentukan bagaimana konten dialog didengar.

Selain dialog kehidupan, dialog isu teologis juga dengan nuansa kesaksian iman, bukan dialog yang berupa pertukaran informasi dan opini. Dialog isu teologis adalah pengkomunikasian kebenaran. Dialog teologis bahkan harus melibatkan masalah iman dalam percakapan yang kadangkala dapat menimbulkan ketidaknyamanan di antara umat beragama (Shenk, 1997). Ada dua hal penting dalam dialog isu teologis, yaitu mendengar definisi orang lain tentang diri mereka (listening to another's self-definition) dan pertanyaan yang mutual (mutual questioning) yang dapat memicu ketegangan, namun haruslah didengar untuk merefleksikan kembali eksistensinya (Shenk, 1997).

Dialog ketiga adalah dialog dalam bentuk kerja sama (formal dan informal). Dialog ini membutuhkan perhatian terhadap persoalan kehidupan seperti: keadilan, perdamaian, pencegahan kriminalitas, rehabilitasi para pecandu narkoba, pendidikan atau kesehatan. Dengan akar maupun metode yang berbeda, umat Kristen harus dapat berkerja sama dengan umat beragama lain, karena dapat mewujudkan perhatian Allah kepada dunia. Dialog ketiga ini, sama dengan dua bentuk dialog sebelumnya, tidak dapat dipisahkan dari bingkai dialog sebagai kesaksian iman.

\section{Penerimaan terhadap penginjilan dan konversi}

Salah satu bagian menarik dari pendekatan Shenk adalah bagaimana ia melihat penginjilan dan konversi pasca dialog. Bagi Shenk, dialog tidak secara eksplisit sama dengan penginjilan, tetapi dialog dapat menjadi kesempatan bersaksi yang otentik untuk menawarkan injil. Menurut Shenk, menawarkan injil adalah hal yang tidak harus dihindari dalam berdialog sebagai saksi Kristus. Sifat dialogs dari iman Kristen tidak lantas membuat sifat misionaris menjadi tergantikan. Mengundang umat beragama lain untuk menerima Yesus dalam dialog bukanlah hal yang tidak pantas, sebab Yesus mengampuni dan memberikan kehidupan baru kepada siapa saja dan iman Kristen tidak dapat menyangkali hal tersebut (Shenk, 1997).

Shenk mendasari penerimaan itu pada sikap bangsa Israel maupun gereja mula-mula yang sejak awal telah dikelilingi agama lain. Menurut hemat Shenk, meskipun dikelilingi agama lain, para nabi tetap menyatakan ketuhanan Allah dan para rasul yang mengklaim ketuhanan Allah di dalam Kristus. Kisah kisah perjanjian baru bahkan berbicara lebih lantang terhadap hal itu, seperti kisah Petrus yang meminta orang bertobat dan dibaptis (Kis 2:38) atau Paulus yang menyatakan pertobatan dan pengampunan dosa (Kis 13:38-39). Itu sebabnya Shenk menilai bahwa penolakan terhadap penginjilan justru merupakan inkonsistensi dari sejarah kekristenan: "if we delete the possibility of conversion in dialogue, that is not consistent with apostolic dialogue. Whenever Jesus Christ is a part of the dialogue, conversion is a part of it as well"(Shenk, 1997). 
Oleh sebab itu, konversi pasca dialog tidak boleh ditolak karena merupakan hasil karya Roh Kudus. Menolak konversi sama dengan dengan menolak karya Roh Kudus. Shenk menegaskan bahwa menghalangi konversi pasca dialog sama dengan membatasi keramahan Allah bagi orangorang di luar kekristenan. Kendati menerima konversi pasca dialog, Shenk sadar sejarah penginjilan masa lalu yang gencar dilakukan para penginjil Barat, membuat konversi sangat akrab dengan semangat triumphalis dan eksplotatif. Bagi Shenk penilaian tersebut tidaklah salah, akan tetapi kegagalan penginjilan-penginjilan sebelumnya tidak boleh membuat gereja menolak penginjilan. Konversi adalah bentuk keramahtamahan Allah yang dirasakan di luar lingkungan Kristen, sehingga tidak harus ditolak.

Dalam penegasan itu, Shenk membedakan antara konversi sebagai hasil penginjilan dengan kristenisasi (proselitisasi). Kristenisasi adalah sebuah paksaan, hasil manipulasi dan eksploitasi kelemahan umat beragama lain (Shenk, 1997), sedangkan konversi yang lahir dari penginjilan bersifat undangan, ramah dan memberdayakan orang untuk menemukan Yesus tanpa paksaan. Penginjilan dilakukan dalam relasi-relasi yang bermakna, bukan relasi yang saling mencurangi dan memperdaya orang lain (Shenk, 1997). Hal seperti ini juga terdapat di dalam Islam, yang disebut oleh Sumanto AlQurtuby sebagai Islamic evangelism. Menurut Al-Qurtuby, Islam memiliki prinsip yang kuat tentang penyebaran agama, seperti yang tertulis dalam Surat An-Nahl (16:125). Islamic evangelism harus dibedakan dengan praktik islamisasi. Bagi Al Qurtuby, menyampaikan, memperkenalkan atau bahkan mengajak orang lain mengikuti tata cara beragama yang kita lakukan adalah hak setiap orang, namun yang terpenting adalah bagaimana menyampaikan agama itu, bagaimana membagikan kepercayaan iman tanpa membuat seseorang merasa diserang adalah hal utama dalam berdakwah (Al-Qurtuby, 2011a) .

\section{Perspektif Teologi Agama-agama dan Realitas Maluku Pasca Konflik}

Pendekatan Shenk sejatinya berusaha untuk mengantar umat Kristen keluar dari kebiasan kebiasan dialog antar agama yang cenderung superfisial dan tidak otentik menurutnya. Shenk berupaya mengimbangi kecenderungan dialog yang terpengaruh pluralisme dengan penegasan tugas kesaksian umat Kristen. Menurut hemat Shenk, dialog seharusnya memuat komunikasi kebenaran iman satu sama lain dan bukan menghindari pembicaraan tentang kekhasan iman. Kendati demikian, dalam dialognya dengan konteks, Shenk terkesan melihat misi termasuk kesaksian dan penginjilan di dalamnya sebagai teologi yang terisolasi dan otonom. Shenk hanya melihat perbedaan agama dan budaya sebagai elemen yang mesti cermati dalam tugas kesaksian. Shenk tidak melihat misi sebagai sesuatu yang terhubung dengan dimensi kehidupan sosial serta memiliki konsekuensi bagi publik yang luas. Alhasil, pendekatan Shenk tidak mengajak umat Kristen untuk peka dengan dinamika politik, ekonomi dan sosial dari sebuah konteks.

Pemahaman agama dalam pendekatan Shenk sejatinya lahir dari definisi yang parsial tentang agama itu sendiri. Kecenderungan itu tampak melandasi berbagai pendekatan teologi agama-agama Kristen maupun studi studi agama di Barat. Kwok Pui-Lan misalnya memberikan analisis postkolonial dalam mencermati kecenderungan tersebut. Menurut Pui-Lan, definisi agama (religion) yang sering menjadi basis dari studi-studi agama adalah kategori agama yang sangat dipengaruhi muatan teologis Kristen. Pui-Lan melihat definisi agama dari teolog Liberal asal Jerman, Frederich Schleiermacher cukup berpengaruh dalam definisi agama yang berkembang dalam studi-studi agama di Barat. Schleiermacher mendefinsikan agama sebagai "intuisi atau kesadaran religius untuk merasakan dan bersatu dengan alam semesta" (Pui Lan, 2005). Selain dikritik karena definisinya yang sangat individualitik, Schleiemacher juga sangat bias dalam melihat agama lain, seperti memberikan tempat yang lebih tinggi kepada monoteisme ketimbang politeisme. Ujungnya, Schleiemacher agama Kristen dilihat sebagai "the most highly developed forms of religions".

Menurut Kwok Pui Lan, definisi semacam itu telah memberi pemahaman bahwa agama (religion) hanya perkara kesadaran religius manusia saja sehingga agama dapat dipisahkan dari dimensi kehidupan yang lain seperti dimensi sosial, ekonomi bahkan politik (Pui Lan, 2005). Konstruksi agama tersebut sarat dengan muatan ideologis sekuler untuk membangun pembedaan 
antara yang "religius" dan "non-religius". Kwok Pui Lan mengutip Richard King yang menyebutkan bahwa memisahkan antara yang "religious" dan "sekuler" adalah kunci dari imajinasi masyarakat Barat modern (Pui Lan, 2005).

Parsialnya definisi tentang agama di Barat cukup membuat pendekatan teologi agama-agama seperti yang diuraikan Shenk sangat abai dengan dimensi lain dari kehidupan manusia. Padahal pemahaman yang holistik terhadap tugas kesaksian umat Kristen sangat penting terutama bagi pelaksanaan dialog antar umat beragama di wilayah pasca konflik bernuansa agama (1999-2004) seperti Maluku. Kesaksian iman di Maluku memiliki tantangan tersendiri. Salah satu yang terlihat di masyarakat adalah upaya mereduksi identitas agama sebagai syarat mutlak dalam pemulihan relasi sosial pasca konflik. Dalam kecenderungan tersebut, masyarakat lebih menonjolkan peran sosial dalam berelasi satu sama lain. Hal ini diuraikan dengan baik oleh Diah Kusumanigrum dalam artikelnya Interdependence versus truth and justice lessons from reconciliation processes in Maluku (Kusumaningrum, 2016).

Hal ini diuraikan dengan baik oleh Diah Kusumanigrum bahwa proses rekonsiliasi pasca konflik di Maluku berbasis pada interdependensi atau saling ketergantungan antara umat beragama (Kusumaningrum, 2016). Terdapat empat situs yang memperlihatkan praktik interdependensi antara umat beragama menjadi pola rekonsiliasi di Maluku. Mulai dari seremoni budaya dan agama (ceremonial site), mutualisme di berbagai bidang kehidupan (functional-quotidian site), hubungan personal yang akrab (neighborhood site) hingga narasi perdamaian di berbagai media (narrative site) (Brauchler, 2014). Interdependensi yang terjalin dalam situs-situs ini dimotivasi oleh keinginan untuk memulihkan kembali kehidupan. Motivasi tersebut juga mendorong kesadaran bahwa pemulihan kehidupan pasca konflik tidak dapat berjalan tanpa kehadiran komunitas agama yang lain (Kusumaningrum, 2016). Akan tetapi, karena sifatnya yang didorong oleh hal-hal pragmatis ketimbang tuntutan moral atau nilai religius tertentu, interdependensi hanya menjadikan peran sosial sebagai basis utamannya (Kusumaningrum, 2017). Identitas agama masih dianggap menjadi wilayah rawan yang harus direduksi. Penekanan pada peran sosial tidak hanya menunjukan adanya demarkasi yang jelas di antara peran sosial dan identitas agama, lebih daripada itu, persoalan agama masih dipandang sebagai hambatan ketimbang jembatan dalam upaya kerja sama di tengah tengah masyarakat.

Kecenderungan tersebut bahkan sangat terlihat dalam ceremonial site bernuansa keagamaan yang selama ini digadang gadang menjadi bukti pulihnya relasi antara umat Islam dan Kristen di Maluku. Ketika hari raya Natal, Idul Fitri atau bahkan Idul Adha dirayakan, umat Islam dan Kristen masih saling mengunjungi dan memberikan ucapan selamat satu sama lain. Akan tetapi, perjumpaan pada ceremonial site itu hanya berhenti pada tataran seremonial semata. Pada batas tertentu, persoalan agama masih menjadi wilayah yang sangat sensitif. Oleh sebab itu perjumpaan dalam ceremonial site sekalipun harus dikelola dengan batasan yang jelas agar tidak menimbulkan polemik (Brauchler, 2014).

Ketika agama seolah olah absen dalam ruang ruang perjumpaan itu, perannya dalam komunitas yang terisolasi justru semakin mengarah kepada teologi antar agama yang triumphalistis dan intoleran. Dalam fenomena segregasi pemukiman misalnya, jika motivasi awal segregasi hanya didasari oleh keiginan untuk mencari rasa aman, di kemudian hari fenomena ini dibumbui lagi dengan motivasi-motivasi teologis. Sumanto Al-Qurtuby dalam disertasinya menemukan adanya motivasi teologis seperti dikotomi suci-najis atau halal-haram dalam fenomena segregasi pemukiman. Beberapa oknum umat Islam menjelaskan bahwa menetap bersama umat Kristen dinilai akan menganggu "kemurnian" karena keberadaan anjing (peliharaan umat Kristen) yang najis dan bunyi lonceng gereja (Al-Qurtuby, 2011).

Tidak hanya umat Islam yang memiliki pemahaman demikian, pemahaman serupa dapat dilihat juga dalam komunitas Kristen. Pemuda-pemuda di wilayah Kristen misalnya, gemar menandai lingkungan pemukimannya dengan lukisan simbol-simbol "religius" seperti bendera Israel, bintang daud, serta huruf-huruf Ibrani. Menurut Al Qurtuby, lukisan grafiti dari simbol-simbol tersebut 
dibuat dengan kesadaran akan keterikatan mereka dengan konflik global antara Israel dan Palestina yang menurut mereka adalah konflik antara umat Kristen dengan Islam (Al-Qurtuby, 2011).

Pemahaman yang mengarah kepada semangat rivalitas itu tidak sekadar muncul akibat pemahaman terhadap kebenaran yang berciri absolut, tetapi juga karena pengaruh konflik yang membuat identitas agama bersifat saling menegasikan, seperti pemahaman bahwa umat Islam sebagai korban dan Kristen sebagai pelaku ataupun sebaliknya (Kusumaningrum, 2017). Pengalaman tersebut membuat teologi-teologi yang berciri triumphalis sangat "laku" di kalangan umat beragama.

Potret yang dualistis ini menunjukan bahwa rekonsiliasi yang terjadi di masyarakat saat ini lebih banyak melibatkan faktor-faktor non-religius seperti membangun ruang-ruang perjumpaan di antara masyarakat, memulihkan kembali akses-akses ekonomi, pendidikan, kesehatan, keamanan dsb. Namun, agama sebagai motif yang paling sering hadir selama konflik justru absen dalam proses rekonsiliasi tersebut. Absennya agama tidak lain karena pemahaman yang normatif tentang agama. Agama kerap kali menjustifikasi motif lain seperti politik dan ekonomi ketika konflik (Iwamony, 2019).

Kecenderungan itu terlihat dari sebutan yang umumnya dipakai untuk mengambarkan konflik di Maluku yaitu konflik bernuansa agama. Penekanan pada "nuansa agama" seringkali membuat perhatian hanya diarahkan kepada aspek justifikasi dari agama, dan pada sisi lain umat beragama menyangkali aspek motivasi yang diberikan agama selama konflik (Budi Hardiman, 2018). Dalam ruang-ruang yang tersegregasi inilah, aspek motivasi itu diceritakan dan menjadi warisan bagi generasi berikutnya. Agama yang tidak dilibatkan dalam proses rekonsiliasi tentunya sangat mengkhawatirkan bagi prospek kehidupan umat beragama di Maluku. Mengkhawatirkan karena aspek-aspek non religius yang menjadi pilar rekonsiliasi pun tidak bebas dari potensi konflik. Sentimentalitas agama yang semakin hari semakin menguat dalam ruang ruang yang terpisah justru sangat rentan untuk dimanipulasi. Bentrokan di Unpatti dan Waringin pada tahun 2011, menunjukan bahwa sentimen agama masih membayangi proses rekonsiliasi pasca konflik (Al-Qurtuby, 2011).

Dalam kaitannya dengan dialog sebagai kesaksian iman, Calvin Shenk menegaskan bahwa semua bentuk dialog, baik dialog kehidupan, dialog formal-informal ataupun dialog teologis, identitas sebagai umat Kristen beserta kekhasan imannya harus tetap digemakan ketimbang disembuyikan. Kesaksian harus tetap diproklamirkan dalam setiap perjumpaan sembari menggunakan cara yang ramah dan etis. Hal ini tentu saja bertolak belakang dengan dinamika umat beragama di Maluku, di mana sentimentalitas agama masih sangat tinggi dan rentan memicu polemik. Atas nama keamanan, demarkasi dalam hal agama dibuat begitu ketat agar tidak saling bersinggungan. Umat beragama dapat saling menerima justru ketika identitas keagamaan mereka tidak ditonjolkan dalam perjumpaan.

Terlebih jika praktik-praktik dialog itu pada akhirnya menghasilkan konversi. Bahwa ketika dalam kesaksian, pendengar kemudian memutuskan secara mandiri untuk menjadi pengikut Kristus, hal itu tentu tidak boleh ditolak begitu saja. Namun dalam konteks seperti Maluku, konversi hasil penginjilan yang ramah sekalipun pasti memiliki konsekuensi publik yang luas. Kendati kesaksian dilakukan dengan ramah dan tidak memaksa, konversi dalam ranah komunal organisatoris tetap sulit diterima, malah dapat dijadikan isu dan provokasi untuk melegitimasi kekerasan (F. Manuputty, 2017). Kerentanan pada isu proselitisme dan konversi bukan sekedar muncul karena konteks pasca konflik, tetapi juga karena konversi dalam sejarah relasi Islam-Kristen di Maluku selalu mengarah kepada penghancuran kesatuan dan stabilitas etnik Maluku. Konversi dan proselitisasi telah menjadi narasi disintegrasi yang menyasar identitas kolektif sebagai masyarakat Maluku sejak kedatangan bangsa Portugis di abad ke-16 hingga masa penjajahan Belanda. Sejarah ini tentu saja masih melekat dalam ingatan beberapa kelompok agama, sehingga menjadi tantangan bagi pendekatan dialog yang menenkankan kesaksian seperti yang digagas Calvin Shenk.

Simbiosis Agama Bagi Perjumpaan Islam-Kristen di Maluku 
Dalam uraiannya tentang kesaksian dan dialog, Shenk memberi tempat yang terlalu sedikit untuk melihat dinamika umat Kristen di berbagai tempat. Shenk memang berangkat dari konteks Amerika yang berciri demokratis sekuler. Isu yang dihadapi Shenk adalah sekularisme, hingga subjektivitas religious (Shenk, 1997). Pergulatan konteks semacam ini membuat kekhasan iman Kristen dengan mudah direduksi. Sehingga penekanan Shenk pada keunikan Yesus dan tugas sebagai saksi dapat dipahami.

Namun dalam konteks Maluku, model dialog Shenk mungkin sekali memicu ketegangan ketimbang mendorong dialog menjadi otentik. Pasalnya, kekhasan iman yang semakin ditegaskan pasca konflik justru menjadi wilayah yang pantang untuk disentuh dengan alasan keamanan.

Oleh sebab itu, pergeseran dalam memahami kekhasan iman untuk berjumpa dengan yang lain sangatlah dibutuhkan. Menarik untuk melihat model simbiosis agama (symbiotic religion) yang digagas oleh Aloysius Pieris (Pieris, 2004)- sebagai landasan teologis bagi dialog antar agama di Maluku. Dalam model simbiosis, Pieris membangun basis teologi agama-agamanya bertumpu pada paham kristologisnya. Hal yang juga dilakukan oleh Calvin Shenk, namun dalam penjabarannya Pieris melihat sisi keunikan Yesus yang berbeda dari Shenk bahkan mengkritisi pemahaman keunikan Yesus yang mendorong lahirnya pendekatan dialog seperti yang diusung Shenk.

Simbiosis agama diawali Pieris dengan mengajukan kritik terhadap kristologi chalcedon yang telah mendominasi berbagai wacana teologis termasuk teologi agama-agama. Bagi Pieris, penekanan kristologis chalcedon untuk mendamaikan perdebatan filosofis tentang keilahian dan kemanusiaan Kristus telah membuat dimensi sosial politik dari perjalanan kehidupan Yesus diabaikan. Bagi Pieris, inkarnasi seyogyanya dilihat dalam terang kehidupan, karya, perkataan, kematian hingga kebangkitan tanpa memisahkan dimensi sosial dan politiknya. Yesus membebaskan korban ketidakadilan dengan kerendahan hati dan kelemahlembutan, tanpa niat mengkonversi. Menurut Pieris, keunikan Yesus justru terletak pada "politik kemiskinan" dan cara Yesus memperjuangkan pembebasan (Pieris, 2004). Bahkan saat kematiannya, penyaliban Yesus tidak terlepas daripada posisi Yesus yang adalah korban dari persekongkolan politik antara kaisar dan elit-elit lokal. Menurut Pieris, dalam bahasa pembebasan, salib mesti dilihat sebagai simbol penaklukan Allah atas Mammon atau simbol kasih yang mengalahkan penindasan.

Salib sejatinya harus menjadi simbol kabar baik yang disampaikan umat Kristen kepada para korban penindasan dan menjadi isu yang diperbincangkan dalam dialog antar agama. Pieris menyatakan bahwa, aspek politik dari kehidupan hingga kematian Yesus justru adalah keunikan Yesus yang sesungguhnya, dan kristologis chalcedon justru mengabaikan apa yang sebenarnya menjadi keunikan Kristus (Pieris, 2004).

Dari analisis Pieris ini, dapat disinyalir bahwa pendekatan dialog seperti yang diusung Calvin Shenk masih berada dalam kerangka kristologi chalcedon. Meskipun dalam uraiannya, Shenk menengaskan bahwa kristologi yang dibangunnya bertolak dari historitas Yesus dalam kitab suci (Jesus event), hal yang ditekankan Shenk tidak lepas dari kerangka kristologi chalcedon, seperti penegasan Yesus sebagai wahyu khusus (special revalation). Penekanan kristologi semacam ini menurut hemat Pieris justru berspekulatif terhadap keunikan Yesus sendiri karena berusaha menangkap aspek misteri dari inkarnasi yang berada diluar verifikasi sejarah.

Dari penekanan itu, Pieris kemudian mengajukan sebuah gambaran kristologi yang ia sebut sebagai kristologi perjanjian (covenant christology). Menurut Pieris, Yesus dalam Perjanjian Baru tidak hanya dilihat sebagai zat individu seperti dalam kristologi chalcedon, tetapi Yesus adalah sosok di mana Allah dan para korban ketidakadilan dapat dijumpai dalam satu pribadi. Kristologi perjanjian itu kemudian dirangkum dalam dua poin. Pertama, Yesus adalah antinomi yang tidak dapat didamaikan antara Allah dengan Mammon (mengasihi Tuhan). Kedua, Yesus adalah fakta pertahanan yang tidak dapat dibatalkan antara Allah dengan orang-orang miskin (mengasihi sesama manusia). Implikasinya, mengasihi Tuhan harus mewujud dalam perjuangan untuk menghidupi kemiskinan injili (evangelism poverty) sedangkan mencintai sesama mewujud dalam perjuangan untuk membela mereka yang miskin secara sosial. Dalam kristologi perjanjian, pembebasan orang miskin adalah syarat bagi keselamatan pribadi (Pieris, 2004). 
Pieris kemudian melihat implikasi gambaran kristologi tersebut dalam konteks kemajemukan antar umat beragama di Asia. Bagi Pieris, pemaknaan Kristus yang melihat Mammon (kekayaan absolut) sebagai musuh bersama memiliki implikasi yang serius bagi relasi antar umat beragama. Mammon sebagai musuh bersama dapat menjadi landasan dialog antar agama, karena dengan menjadikan kemiskinan dan pembebasan sebagai platform dialog, kekristenan tidak bersaing dengan agama-agama lain tetapi saling bekerja sama dan melengkapi satu sama lain.

Lebih lanjut, bagi Pieris, relasi saling melengkapi itu telah tampak dari perjumpaan komunitas basis manusiawi (basic human communities) dalam konteks Sri Lanka antara umat Kristen dan Buddha. Dalam perjuangan melawan perang, korupsi dan kemiskinan, umat Kristen di Sri Lanka belajar banyak dari spiritualitas Buddha yang dipraktikan para bikshu, dalam wujud kehidupan yang menentang keras keserakahan (hawa napsu) serta menjadi miskin secara sukarela. Potret itu menurut Pieris menunjukan bahwa hubungan agama-agama di Asia tidak hanya berbentuk sinkretis dan sintesis, tetapi juga simbiosis. Alih-alih mempertentangkan kekhasan tradisi agama lain, dalam simbiosis, kekhasan tradisi iman antar agama justru saling melengkapi satu sama lain. Pieris kemudian menyebutnya sebagai model simbiosis agama (symbiosis of religion) (Pieris, 2013).

Menurut Pieris, setiap agama memiliki pengalaman dasar pembebasan (primordial experience of liberation) yang dapat menginspirasi praktik praktik liberatif (Pieris, 2004). Hal ini dapat menjadi pijakan awal bagi terciptanya relasi yang berciri simbiosis. Lebih jauh menurut Pieris, dalam simbiosis, setiap agama akan ditantang oleh pendekatan-pendekatan yang unik dari agama lain dalam semangat pembebasan bagi mereka yang menjadi korban ketidakadilan. Tanggapan terhadap pendekatan-pendekatan yang unik itu justru akan membantu umat beragama untuk menemukan kembali kekhasan agamanya. Dalam proses simbiosis itu pula agama-agama dapat disadarkan bahwa masing-masing kekhasan tradisi agama tidak selalu bersifat kontradiktif dan eksklusif tetapi juga bersifat komplementer atau saling melengkapi. Bukan saling mengeliminasi tetapi justru dapat saling mengkoreksi dan melengkapi secara mutual dalam upaya memperjuangkan pembebasan.

Dalam konteks Maluku, simbiosis agama mungkin sekali menjadikan proses pemulihan kehidupan bersama pasca konflik sebagai landasan konkrit untuk memulai dialog. Faktor-faktor yang dapat memicu konflik seperti kemiskinan maupun ketidakadilan harus menjadi common ground bagi dialog antar umat beragama di Maluku. Hal yang sama juga dilakukan pada aspekaspek non religius yang selama ini menjadi pilar bagi proses rekonsiliasi. Alih-alih mencabut keterlibatan agama, aspek non religius itu justru harus dijadikan landasan bersama yang terus dikawal dalam dialog antar umat beragama. Semangat rivalitas antar agama yang kuat harus diganti dengan semangat kemitraan untuk melawan penindasan dan ketidakadilan.

Proses perjumpaan untuk mengawal proses pemulihan kehidupan itu tentu saja akan memperjumpakan kekhasan tradisi dari kedua agama. Alih-alih mereduksi kekhasan, perjumpaan antar kekhasan itu justru dapat membuat kedua komunitas semakin mengenal panggilannya masingmasing. Dalam praksis berdialog, kerentanan yang terjadi saat berdialog tidak lagi menjadi ruang untuk konversi seperti yang ditegaskan Shenk, tetapi justru menjadi awal bagi dimulainya dialog intra agama. Otentiknya sebuah dialog justru memungkinkan peserta dialog untuk melakukan dialog intra agama untuk semakin mengenal keunikan agamanya.

Potret ini sangat mungkin terjadi manakala umat Islam maupun Kristen dimampukan untuk melakukan pergeseran paradigmatis terhadap konsep misi dan dakwah. Kedua konsep yang selama ini berwajah antagonis, dalam perjumpaan simbiosis justru dapat didefinisikan kembali. Seperti yang ditekankan Pieris, umat Kristen mungkin sekali melakukan pergeseran paradigmatis dari misi yang menekankan proklamasi dan konversi kepada panggilan untuk mewujudkan kehidupan Yesus yang solider dengan orang miskin dan melawan kuasa opresif yang merusak kehidupan.

Begitupun dengan dakwah, umat Islam sangat mungkin melakukan pergeseran paradigmatis dari dakwah yang menekankan proselitisasi kepada dakwah yang liberatif. Waryono dalam tulisannya Dakwah Islam dan interaksi interkultural menegaskan bahwa salah satu tugas dakwah adalah yanhaunna 'anil munkar atau mencegah kemungkaran. Tugas mencegah kemungkaran itu dapat ditafsirkan dalam bingkai liberasi sehingga dakwah harus mencegah kemungkaran 
kemungkaran dalam bidang sosio-ekonomi. Dari pergeseran itu dakwah akan berorientasi untuk mengadvokasi orang orang yang tertindas. Dalam hal ini, Waryono Abdul Gafur menjelaskan:

Salah satu tugas Da'i dalam berdakwah adalah yanhaunna 'anil munkar atau mencegah kemungkaran. Kemungkaran dapat dilihat dalam berbagai bentuk kedzaliman termasuk di dalamnya kemungkaran ekonomi. Dalam konteks demikian, nahi mungkar sebagai bentuk dakwah dapat ditafsirkan sebagai liberasi, yang berarti memerdekakan orang dari penindasan. Waryono menunjukan bahwa dakwah dalam tugasnya itu justru bertendensi untuk melakukan advokasi kepada orang-orang yang tertindas (Waryono Abdul Gafur, 2015).

Dari redefinisi itu, umat Kristen maupun Islam memperoleh pijakan teologis yang kuat dalam relasi yang berciri simbiosis. Konsep misi maupun dakwah yang sebelumnya justru menjadikan agama saling bertempur ketika konflik (Al-Qurtuby, 2011), bahkan menjadi hambatan teologis dalam proses rekonsiliasi, dalam simbiosis agama, justru bersinergi satu sama lain untuk memperjuangkan pemulihan kehidupan bagi masyarakat Maluku pasca konflik. Misi dan dakwah tidak lagi berkontestasi dalam usaha untuk menambah jumlah anggota, tetapi bekerja sama untuk melakukan pembebasan guna merawat proses rekonsiliasi pasca konflik di Maluku.

Oleh karena itu, dengan pola interdependensi yang telah terjalin pada aspek-aspek non religius, model simbiosis agama tampaknya akan sangat relevan bagi konteks Maluku. Hubungaan saling ketergantungan pada ranah sosial, politik dan ekonomi dapat dilengkapi dengan simbiosis dalam pemahaman hubungan antar agama. Agama tidak lagi absen dalam upaya-upaya rekonsiliasi pasca konflik, tetapi bergerak aktif mendorong umat beragama untuk berjalan bersama merawat kehidupan bersama sembari mendorong pengenalan yang semakin dalam terhadap keunikan masing masing tradisi agama.

\section{Simpulan}

Dari uraian di atas, dapat dilihat bahwa standar otentiknya suatu dialog antar agama tidak dapat disamakan dalam setiap konteks. Shenk yang bergelut dalam konteks Amerika seperti sekularisme dan subjektivitas religius membutuhkan penekanan yang radikal akan keunikan Kristus dalam berdialog dengan umat beragama lain. Tidak mengherankan jika standar otentiknya dialog menurut Shenk adalah ketika umat beragama mampu untuk saling mengkomunikasikan kekhasan imannya. Standar ini belum tentu relevan bagi konteks Maluku yang bergelut dengan upaya pemulihan relasi pasca konflik. Dalam konteks relasi umat Islam dan Kristen di Maluku, otentiknya sebuah dialog justru tidak berhenti pada upaya saling memahami, tetapi lebih daripada itu, dialog yang otentik harus mendukung upaya rekonsilisasi dan mendorong umat beragama untuk semakin mengenal keunikan iman, bahkan menyadari sungguh bahwa agama-agama selalu saling bersimbiosis di dalam kekhasan tradisi imannya.

\section{Referensi}

Al-Qurtuby, S. (2011a). Among the Believers. Semarang: Elsa.

Al-Qurtuby, S. (2011b). Interligious Violence, Civic Peace, and Citizenship Christian and Muslims in Maluku Eastern Indonesia. Boston University.

Bahri, M. Z. (2014). Dialog antar Iman dan Kerja Sama Demi Harmoni Bumi. Refleksi, 13(1). https://doi.org/10.15408/ref.v13i1.993

Brauchler, B. (2014). Christian-Muslim Relations in Post-Conflict Ambon, Moluccas, Adat, Religion and Beyond (In Religio; B. Platzdasch \& J. Saravanamuttu, Eds.). Pasir Pajang: Institue of South Asian Studies.

Budi Hardiman, F. (2018). Demokrasi dan Sentimentalitas. Yogyakarta: PT Kanisius.

F. Manuputty, J. (2017). Meretas Jalan Damai Berbasis Masyarakat Dan Agama: Dari Maluku Untuk Indonesia Dan Dunia. In I. Ali Fauzi (Ed.), Ketika Agama bawa Damai, Bukan Perang: Belajar dari Imam dan Pastor (Ketika Aga). Jakarta: PUSAD Paramadina.

Hick, J. (1993). Disputed Questions in Theology and the Philosophy. London: MacMillan.

Iwamony, R. (2019). Majority versus Minority. Proceedings of the International Conference on Religion and Public 
Civilization (ICRPC 2018). https://doi.org/10.2991/icrpc-18.2019.21

Kamarusdiana, K. (2018). Al-Qur'an dan Relasi Antar Umat Beragama; Diskursus Tentang Pendidikan Pluralisme Agama di Indonesia. SALAM: Jurnal Sosial Dan Budaya Syar-I, 5(3), 241-254. https://doi.org/10.15408/sjsbs.v5i3.9811

Kusumaningrum, D. (2016). Interdependence versus Thruth and Juctice: Lessons from Reconciliation Processes in Maluku. Jurnal Ilmu Sosial Dan Ilmu Politik, 20(1).

Kusumaningrum, D. (2017). Belajar Dari Rekonsiliasi Sehari-Hari Di Maluku. In I. Ali Fauzi (Ed.), Ketika Agama bawa Damai, Bukan Perang: Belajar dari Imam dan Pastor (Ketika Aga). Jakarta: PUSAD Paramadina.

Magnis Suseno, F. (2003). Dialog Antar Agama di Jalan Buntu. In S. Hardiyanto (Ed.), Agama dalam Dialog: Pencerahan, Pendamaian, dan Masa Depan. Jakarta: BPK Gunung Mulia.

Moko, C. W. (2017). Pluralisme Agama Menurut Nurcholish Madjid (1939-2005) dalam Konteks Keindonesiaan. Jurnal Intelektualita, 6(1).

Mujib, I., \& Z. Rumahuru, Y. (2010). Paradigma Transformatif Masyarakat Dialog: Membangun Fondasi Dialog AgamaAgama Berbasis Teologi Humanis. Yogyakarta: Pustaka Pelajar.

Pieris, A. (2004). Political Theologies of Asia. In P. Scott \& W. . Cavanaugh (Eds.), The Blackwell Companion to Political Theology (In The Bla). Oxford: Blackwell.

Pieris, A. (2013). The Genesis of an Asian Theology of Liberation. Sri Langka: Tulana Jubilee Publications.

Pui Lan, K. (2005). Postcolonial Imagination \& Feminist Theology. Louisville: Westminster John Knox Press.

Rahmat, S. T. (2017). Dialog Antropologis Antaragama dengan Spiritualitas Passing Over. Wawasan: Jurnal Ilmiah Agama Dan Sosial Budaya, 2(2), 181-198. https://doi.org/10.15575/jw.v2i2.1704

Shenk, C. E. (1997). Who Do You Say That I Am? Christians Encounter Other Religions. Scottdale: Herald Press.

Shenk, C. E. (2010). Book Review: Christianity Encountering World Religions: The Practice of Mission in the Twenty-First Century. Missiology: An International Review, 28(1), 245-246.

Sugiyono. (2016). Metode Penelitian Dan Pengembangan (Research and Development/RED). Bandung: Alfabeta.

Susanto, E. (2007). Multikulturalisme Pendidikan Agama Islam (Telaah atas Pemikiran Nurcholish Madjid). TADRIS: Jurnal Pendidikan Islam, 2(2).

Wahyuni, D. (2019). Gerakan Dialog Keagamaan: Ruang Perjumpaan Antar Umat Beragama Di Kota Bandung. Religious: Jurnal Studi Agama-Agama Dan Lintas Budaya, 3(2), 188-197.

Waryono Abdul Gafur. (2015). Dakwah Islam dan Interaksi Interkultural. In K. de Jong \& Y. Tridarmanto (Eds.), Teologi dalam Silang Budaya. Yogyakarta: TPK dan Fakultas Teologi Universitas Kristen Duta Wacana.

Yoder, J. J. (1994). The Trinity and Christian Witness to Muslims. Missiology: An International Review, 22(3), 339346. https://doi.org/10.1177/009182969402200303

Zaprulkhan, Z. (2018). Dialog dan Kerjasama Antar Umat Beragama dalam Perspektif Nurcholish Madjid. Mawa'izh: Jurnal Dakwah Dan Pengembangan Sosial Kemanusiaan., 9(2), $154-177$. https://doi.org/10.32923/maw.v9i2.783

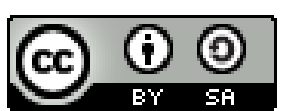

(C) 2020 by the authors. Submitted for possible open access publication under the terms and conditions of the Creative Commons Attribution (CC BY SA) license (https://creativecommons.org/licenses/by-sa/3.0/). 